\section{RMD Open}

Rheumatic \&

Musculoskeletal Diseases

\title{
Change in cardiovascular risk factors in patients who develop psoriatic arthritis: longitudinal data from the Nord- Trøndelag Health Study (HUNT)
}

Agnete Malm Gulati, ${ }^{1,2}$ Øyvind Salvesen, ${ }^{3}$ Ruth Stoklund Thomsen, ${ }^{1,4}$ Arthur Kavanaugh, ${ }^{5}$ Anne Grete Semb, ${ }^{6}$ Silvia Rollefstad, ${ }^{6}$ Glenn Haugeberg, ${ }^{7,8}$ Mari Hoff ${ }^{1,4}$

To cite: Gulati AM, Salvesen $\emptyset$, Thomsen RS, et al. Change in cardiovascular risk factors in patients who develop psoriatic arthritis: longitudinal data from the Nord-Trøndelag Health Study (HUNT). RMD Open 2018;4:e000630. doi:10.1136/ rmdopen-2017-000630

- Prepublication history for this paper is available online. To view these files, please visit the journal online (http://dx.doi. org/10.1136/rmdopen-2017000630).

Received 5 December 2017 Revised 13 February 2018 Accepted 21 February 2018

\section{ABSTRACT}

Objectives The aim of this population-based study was to compare changes in cardiovascular (CV) risk factors over a decade-long period in patients who developed psoriatic arthritis (PsA) and the background population.

Methods Patients diagnosed with PSA $(n=151)$ between 1998 and 2008 and matched controls $(n=755)$ who participated in both the Nord-Trøndelag Health Study (HUNT) 2 (1995-1997) and HUNT3 (2006-2008) were included. Mixed linear and logistic models were used to analyse the difference in mean change between HUNT2 and HUNT3 in patients and controls for body mass index (BMI), total cholesterol (TC), triglycerides, low-density lipoprotein cholesterol (LDL-c), high-density lipoprotein cholesterol (HDL-C) and blood pressure (BP).

Results At baseline (HUNT2), the patients who developed PsA compared with controls had higher BMI (27.2 vs $\left.25.9 \mathrm{~kg} / \mathrm{m}^{2}, \mathrm{p}<0.001\right)$ and lower HDL-C (1.32 vs $1.40 \mathrm{mmol} / \mathrm{L}, \mathrm{p}<0.03$ ) and more were smokers (41.1 vs $28.5 \%, p<0.01)$. Seventy-eight per cent had skin psoriasis. The mean PSA disease duration at HUNT3 was $4.8(+/-3.0)$ years. The patients who developed PsA gained less weight from HUNT2 to HUNT3 compared with the control group ( $2.1 \mathrm{vs} 3.9 \mathrm{~kg}$, difference in mean change $-1.8 \mathrm{~kg}, 95 \% \mathrm{Cl}$ -3.9 to $-0.5, p<0.01)$. TC, triglycerides, LDL-C or HDL-C values and $\mathrm{BP}$ declined in both groups, with no significant differences between groups.

Conclusion Longitudinal 10-year data did not show an increase in CV risk factors in patients who developed PsA compared with controls. This study implies that unfavourable CV risk factors in PsA were present before the diagnosis was established.

\section{BACKGROUND}

Psoriatic arthritis (PsA) is an inflammatory joint and musculoskeletal disease characterised by synovial and enthesal inflammation. Several studies have demonstrated an increased prevalence of cardiovascular (CV) risk factors in patients with PsA. ${ }^{1-5} \mathrm{~A}$ systematic review concluded with increased $\mathrm{CV}$ morbidity in patients with PsA, including

\section{Key messages}

What is already known about this subject?

- The increased risk of cardiovascular (CV) disease in patients with psoriatic arthritis (PsA) can to some extent be explained by increased prevalence of traditional CV risk factors and the presence of skin psoriasis.

- Data on changes in CV risk factors over time in patients with PsA are lacking.

What does this study add?

- This population-based study investigated the course of body weight, cholesterol, blood pressure (BP) and smoking habits, from 1995 to 2008 in patients who were diagnosed with PsA during this period.

- This study implies that unfavourable CV risk factors in PSA were present before the diagnosis was established, perhaps as a result of pre-existing skin psoriasis.

How might this impact on clinical practice?

- As unfavourable CV risk factors in patients with PsA were present before the diagnosis was established, the focus on $\mathrm{CV}$ disease prevention must begin when the patient presents with psoriasis.

myocardial infarction, cerebrovascular and peripheral vascular disease. ${ }^{4}$ We have previously reported increased prevalence of obesity, hypertension, triglyceride level and angina pectoris in patients with PsA from the Nord-Trøndelag Health Study (HUNT) $3 .^{3}$ Whether increased CV risk factors are present prior to diagnosis of PsA or a result of the disease itself has not been clarified. ${ }^{6}$ Unlike rheumatoid arthritis (RA), where a decrease in body mass index (BMI) and lipids over the disease course is well recognised, there is a paucity of studies exploring changes in 
Table 1A Demographics of the patients developing PsA and controls at HUNT2 (observed values)

\begin{tabular}{|c|c|c|c|c|c|}
\hline & $\begin{array}{l}\text { Patients who } \\
\text { develop PsA } \\
(n=151)\end{array}$ & $\begin{array}{l}\text { Matched controls } \\
(n=755)\end{array}$ & P values* & $\begin{array}{l}\text { Non-matched } \\
\text { controls }(n=36812)\end{array}$ & $P$ values $†$ \\
\hline Female sex, n (\%) & $87(57.6)$ & $435(57.6)$ & NA & $20314(55.2)$ & 0.55 \\
\hline Age, years (SD) & $43.8(10.1)$ & $43.8(10.1)$ & NA & $47.1(13.4)$ & $<0.001$ \\
\hline $\begin{array}{l}\text { Married or partner, } \\
\mathrm{n}(\%)\end{array}$ & $102(67.5)$ & $521(69.0)$ & 0.61 & $24839(67.5)$ & 0.98 \\
\hline Skin psoriasis, n (\%) & $100 / 128(78.1)$ & NA & NA & NA & NA \\
\hline Weight, kg (SD) & $80.4(15.5)$ & 76.0 (13.5) & $<0.001$ & 76.4 (13.6) & $<0.001$ \\
\hline Height, cm (SD) & $170.0(8.6)$ & $170.8(9.1)$ & 0.19 & $170.7(9.0)$ & 0.30 \\
\hline $\begin{array}{l}\text { Body mass index, } \\
\mathrm{kg} / \mathrm{m}^{2} \text { (SD) }\end{array}$ & $27.2(4.5)$ & $25.9(3.7)$ & $<0.001$ & $26.2(3.9)$ & $<0.01$ \\
\hline $\begin{array}{l}\text { Current smoking, } \\
\mathrm{n}(\%)\end{array}$ & $62(41.1)$ & $215(28.5)$ & $<0.01$ & $9341(26.6)$ & $<0.001$ \\
\hline $\begin{array}{l}\text { Total cholesterol, } \\
\mathrm{mmol} / \mathrm{L} \text { (SD) }\end{array}$ & $5.85(1.16)$ & $5.77(1.16)$ & 0.47 & $5.83(1.2)$ & 0.87 \\
\hline $\begin{array}{l}\text { HDL cholesterol, } \\
\mathrm{mmol} / \mathrm{L} \text { (SD) }\end{array}$ & $1.32(0.35)$ & $1.40(0.39)$ & 0.03 & $1.39(0.38)$ & 0.01 \\
\hline $\begin{array}{l}\text { LDL cholesterol, } \\
\mathrm{mmol} / \mathrm{L} \text { (SD) }\end{array}$ & $\begin{array}{l}4.83(1.04) \\
(n=146)\end{array}$ & $\begin{array}{l}4.81(1.05) \\
(n=735)\end{array}$ & 0.87 & $\begin{array}{l}3.68(1.08) \\
(n=35774)\end{array}$ & 0.83 \\
\hline $\begin{array}{l}\text { Triglycerides, } \\
\mathrm{mmol} / \mathrm{L} \text {, median } \\
\text { (IQR) }\end{array}$ & $1.87(1.23)$ & $1.69(1.10)$ & 0.08 & $1.7(1.09)$ & 0.05 \\
\hline $\begin{array}{l}\text { Systolic blood } \\
\text { pressure, mm Hg } \\
\text { (SD) }\end{array}$ & $132.7(15.0)$ & $131.5(16.6)$ & 0.40 & $132.7(15.0)$ & 0.35 \\
\hline $\begin{array}{l}\text { Diastolic blood } \\
\text { pressure, } \mathrm{mm} \text { Hg } \\
\text { (SD) }\end{array}$ & $79.9(10.1)$ & $79.1(10.7)$ & 0.41 & 79.5 (11.3) & 0.68 \\
\hline
\end{tabular}

$P$ values for difference between PsA and matched controls analysed with mixed linear and logistic analysis.

Unless stated, continuous values are mean (SD), categorical values are number (\%).

${ }^{*}$ Comparing patients with PsA and matched controls.

†Comparing patients with PsA and all non-matched controls.

HDL, high-density lipoprotein; HUNT, Nord-Trøndelag Health Study; LDL, low-density lipoprotein; PsA, psoriatic arthritis.

$\mathrm{CV}$ risk factors in patients with PsA. ${ }^{78}$ The aim of this study was to compare changes in $\mathrm{CV}$ risk factors between HUNT2 (1995-1997) and HUNT3 (2006-2008) in patients who are diagnosed with PsA in this time period and the background population.

\section{RESEARCH DESIGN AND METHODS \\ Study population}

Patients were recruited from the population-based HUNT studies, which have been performed three times: HUNT1 (1986-1988), HUNT2 (1995-1997) and HUNT3 (20062008). Nord-Trøndelag is one of 19 Norwegian counties and is located in the middle part of the country. Description of the HUNT studies has been published in detail. ${ }^{9}$ A total of 93680 adults were eligible for participation in HUNT3, and out of these 50807 participated (54\%). In HUNT3, 338 persons $(0.67 \%)$ were validated to have PsA according to the ClASsification of Psoriatic ARthritis (CASPAR) criteria. ${ }^{10}$ All the patients had a diagnosis of psoriasis verified by a dermatologist or a rheumatologist as well as arthritis at peripheral joints and/or at spine verified by a rheumatologist. The diagnosis of spinal involvement was based on inflammatory back pain (IBP) and limitation of motion of the lumbar spine. IBP was defined as chronic low back pain that improves with exercise and is not relieved with rest; insidious onset; onset before the age of 40 years and pain at night. This study includes 37070 persons who participated in both HUNT2 and HUNT3. Of 338 PsA cases identified in HUNT3, 151 were diagnosed between HUNT2 and HUNT3 (through 2008) and included in this study. Patients diagnosed with PsA before HUNT2 were excluded. The persons who developed PsA were compared with non-PsA controls matched in a 1:5 ratio for age and sex $(n=755)$.

\section{OUTCOME MEASURES}

Changes in the following CV risk factors were the outcomes of interest: weight, BMI, blood pressure (BP), 
Table 1B Disease characteristics of the patients with PsA at HUNT3 (2008)

\begin{tabular}{|c|c|c|c|}
\hline $\begin{array}{l}\text { Disease } \\
\text { characteristics }\end{array}$ & $\begin{array}{l}\text { All } \\
(n=151)\end{array}$ & $\begin{array}{l}\text { Male } \\
(n=64)\end{array}$ & $\begin{array}{l}\text { Female } \\
(n=87)\end{array}$ \\
\hline $\begin{array}{l}\text { PsA disease } \\
\text { duration, years } \\
\text { (SD) }\end{array}$ & $4.8(3.0)$ & $5.3(3.2)$ & $4.5(2.8)$ \\
\hline $\begin{array}{l}\text { Skin psoriasis } \\
\text { disease duration, } \\
\text { years, median } \\
\text { (IQR) }(n=78)\end{array}$ & $9.0(12.3)$ & $9.0(12.3)$ & $8.5(12.8)$ \\
\hline $\begin{array}{l}\text { Skin psoriasis } \\
\text { symptom duration, } \\
\text { years, median } \\
(\text { IQR) }(n=130)\end{array}$ & $20(24.4)$ & $18.9(21.5)$ & $21.2(28.4)$ \\
\hline $\begin{array}{l}\text { Peripheral joint } \\
\text { involvement, n (\%) }\end{array}$ & $146(96.7)$ & $62(96.9)$ & $84(96.6)$ \\
\hline $\begin{array}{l}\text { Axial involvement, } \\
\text { n (\%) }\end{array}$ & $43(28.5)$ & $20(31.3)$ & $23(26.4)$ \\
\hline Enthesitis, n (\%) & $101(66.9)$ & $43(67.2)$ & $58(66.7)$ \\
\hline $\begin{array}{l}\text { CRP value, median } \\
\text { (IQR) }\end{array}$ & $\begin{array}{l}4.0(4) \\
(n=143)\end{array}$ & $\begin{array}{l}4.0(4) \\
(n=59)\end{array}$ & $\begin{array}{l}4.0(6) \\
(n=84)\end{array}$ \\
\hline $\begin{array}{l}\text { ESR value, median } \\
\text { (IQR) }\end{array}$ & $\begin{array}{l}9.0(14) \\
(n=139)\end{array}$ & $\begin{array}{l}6.0(9) \\
(n=57)\end{array}$ & $\begin{array}{l}10.0(15) \\
(n=82)\end{array}$ \\
\hline \multicolumn{4}{|c|}{ Ever use of peroral steroids, $n(\%)$} \\
\hline Previous & $66(43.7)$ & $22(34.4)$ & $44(50.6)$ \\
\hline Current & $6(4.0)$ & $3(4.7)$ & $3(3.4)$ \\
\hline \multicolumn{4}{|c|}{ Ever users of anti-TNF therapy, $\mathrm{n}(\%)$} \\
\hline Previous & $10(6.6)$ & $1(1.6)$ & $9(10.3)$ \\
\hline Current & $15(9.9)$ & $6(9.4)$ & 9 (10.3) \\
\hline \multicolumn{4}{|c|}{ Ever use of methotrexate, n (\%) } \\
\hline Previous & $29(19.2)$ & $10(15.6)$ & $19(21.8)$ \\
\hline Current & $45(29.8)$ & $21(32.8)$ & $24(27.6)$ \\
\hline
\end{tabular}

Ever use of synthetic DMARDs other than methotrexate, n (\%)

\begin{tabular}{llll} 
Leflunomide & $37(24.5)$ & $12(18.8)$ & $25(28.7)$ \\
Sulfasalazin & $8(5.3)$ & $2(3.1)$ & $6(6.9)$ \\
\hline
\end{tabular}

Unless stated, continuous values are mean (SD), categorical values are number (\%).

CRP, $\mathrm{C}$ reactive protein; DMARD, disease modifying antirheumatic drug; ESR, erythrocyte sedimentation rate; HUNT3: Health Study in Nord-Trøndelag 3; PsA, psoriatic arthritis; TNF, tumour necrosis factor.

cholesterol, triglycerides and smoking. The disease characteristics of the 151 patients with PsA, including use of synthetic and biological disease modifying antirheumatic drugs (DMARDs) were obtained from reviewing patient hospital medical records through 2008. The only biological DMARDs available in Norway at the time of the study were tumour necrosis factor inhibitors, and the hospital is the exclusive prescriber of this medication to all patients. $\mathrm{C}$ reactive protein and erythrocyte sedimentation rate values were only available in the HUNT3 study. BP was measured with Dinamap 845XT Criticon apparatus. The

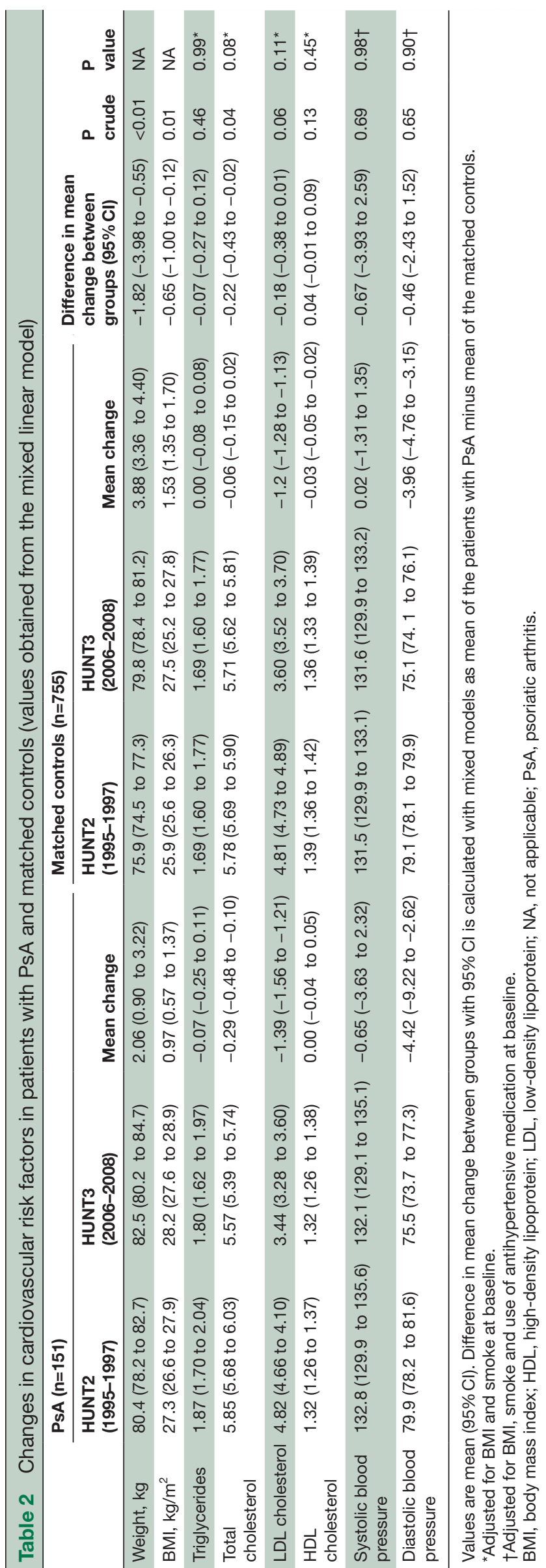


average of the second and third measurement was used. Smoking was reported as daily smoking of cigarettes. Non-fasting blood samples were analysed in $\mathrm{mmol} / \mathrm{L}$ for triglycerides, total cholesterol (TC) and high-density lipoprotein cholesterol (HDL-c) by standardised methods at Levanger hospital. Low-density lipoprotein cholesterol (LDL-c) was calculated using the Friedewald formula (TC - HDL-c - (triglycerides/2.2)) excluding those with triglyceride concentrations $\geq 4.5 \mathrm{mmol} / \mathrm{L}^{11}$

\section{STATISTICAL ANALYSES}

Statistical analyses were performed with SPSS for Mac V.21 (Chicago, Illinois, USA) and R for Windows. Statistical significance level was set at $\mathrm{p}<0.05$. The demographical data were compared with mixed models to account for the matching design and also compared with the whole HUNT population. Diagnosis of PsA was registered as a dichotomous variable. Differences in mean change from HUNT2 to HUNT3 in weight, BMI, lipids and BP between the two groups with $95 \%$ CI were calculated with mixed linear models, to account for the correlations between repeated measurements within each patient, the matching design and missing values. For BP and lipids, possible confounding variables (BMI, smoking and use of antihypertensive medication at HUNT2 and HUNT3) were also added to the mixed model. The proportion of smokers in HUNT2 and HUNT3 were compared with Fisher's exact test because of small numbers.

\section{RESULTS}

As shown in table $1 \mathrm{~A}, 57.6 \%$ were females, and mean age \pm SD was $43.8 \pm 10.1$ years. At baseline (HUNT2), the patients who developed PsA compared with controls had higher BMI (27.2 vs $\left.25.9 \mathrm{~kg} / \mathrm{m}^{2}, \mathrm{p}<0.001\right)$ and lower HDL-c (1.32 vs $1.40 \mathrm{mmol} / \mathrm{L}, \mathrm{p}<0.03)$, and more were smokers (41.1 vs $28.5 \%, \mathrm{p}<0.01)$. Seventy-eight per cent had skin psoriasis. The mean $( \pm \mathrm{SD})$ PsA disease duration at HUNT3 was $4.8 \pm 3.0$ years, and mean $( \pm \mathrm{SD})$ disease duration of skin psoriasis at HUNT3 was 11.4 \pm 10.4 years (table 1B). The number of patients with PsA currently using methotrexate, leflunomide and biological DMARDs in 2008 was $45(24.9 \%), 37(24.2 \%)$ and 15 (9.9\%), respectively.

Table 2 shows the difference in mean change in $\mathrm{CV}$ risk factors between HUNT2 and HUNT3 in patients with PsA and controls. The patients with PsA gained less weight compared with the control group (2.1 vs $3.9 \mathrm{~kg}$ ), with a significant difference in mean change of $-1.8 \mathrm{~kg}$ (95\% CI -3.9 to $-0.5, \mathrm{p}<0.01)$. Patients with PsA had a greater reduction in TC values compared with the controls, with difference in mean change between groups of -0.22 $\mathrm{mmol} / \mathrm{L}(\mathrm{p}=0.04)$, however, adding BMI and smoking to the mixed linear model attenuated the association $(\mathrm{p}=0.08)$. Both groups showed a reduction in diastolic $\mathrm{BP}$ and stable systolic BP, without significant difference between groups. Of all the smokers in HUNT2, $56.5 \%$ of the patients with PsA still smoked in HUNT3 versus 54.0\% of the controls $(\mathrm{p}=0.75)$. More patients with PsA started smoking during the decade compared with controls $(8.5$ vs $3.1 \%, \mathrm{p}=0.03$ ).

\section{DISCUSSION}

Longitudinal data from this observational study did not show an increase in CV risk factors in patients who develop PsA compared with controls. In fact, the PsA group experienced a smaller increase in weight during the decade from HUNT2 to HUNT3. However, at baseline, the patients who developed PsA had higher BMI, lower HDL-c and were more often smokers compared with the control group. This may be explained by the fact that $78 \%$ in this group had psoriasis symptoms at baseline, and psoriasis is associated with high BMI and other $\mathrm{CV}$ risk factors. ${ }^{12}$

To our knowledge, there is a paucity of studies exploring the development of $\mathrm{CV}$ risk factors over time in patients with PsA. In RA, it has been shown that there is no difference in development of CV risk factors compared with non-RA controls after disease onset for hypertension, high BMI or diabetes mellitus. ${ }^{7}$ In fact, patients with RA are more likely to develop low BMI and less likely to develop dyslipidaemia over the course of their disease compared to non-RA patients, related to disease-activity. ${ }^{7}$ However, increased body fat mass with loss of muscle mass is reported in patients with RA. ${ }^{13}$

The strong association between obesity and PsA is well recognised and reported in several studies. ${ }^{3414}$ Increased BMI in early adulthood is suspected to be a predictor of PsA. ${ }^{6}$ Likewise, it has been shown that in patients with psoriasis, the PsA incidence rate increases with increasing BMI. ${ }^{15}$ However, it has also been hypothesised that the PsA diagnosis leads to a further increase in BMI because of less physical activity from pain and disease activity. Result from this study favours that the increased BMI in patients with PsA is present before the diagnosis. The relationship between obesity, psoriatic disease and CV disease is recently starting to become clear. Adipose tissue is a source of several different adipokines that drive inflammation in psoriatic disease. ${ }^{16}$ These adipokines are also important in the development of metabolic syndrome and CV disease and may be an important link between psoriatic disease and CV disease.

Of the patients with PsA included in this study, $78 \%$ had psoriasis symptoms at baseline in HUNT2, before the PsA diagnosis. Thus, we hypothesise that the increased weight before PsA diagnosis may be associated with psoriasis, as high BMI is also associated with this disease. ${ }^{12} 16$ This study implies that further increase in weight in patients with psoriasis who develop arthritis does not happen. However, time of clinical diagnosis of PsA is probably preceded by a 'preclinical phase', that we as yet know little about. It is believed that this phase may already be associated with comorbidities and physiological changes, as proved in RA. ${ }^{17-19}$ This can make interpretation of comorbidities related to PsA before and 
after clinical diagnosis difficult, especially in the setting of already having the systemic inflammatory disease of psoriasis. The smaller weight gain in patients with PsA compared with controls may partially be explained by the patients with PsA being heavier at baseline. Further, the medical attention they receive as a consequence of the PsA diagnosis may include lifestyle interventions for weight loss.

Triglycerides, TC and LDL-c levels declined from HUNT2 to HUNT3, with no difference between patients with PsA and controls. This is in line with other studies demonstrating a decline in lipids in the general population. ${ }^{2021}$ We did not have information on use of statins; however, data from 2016 estimated that between $21 \%$ and $28 \%$ of the drop in TC could be explained by treatment with statins. ${ }^{21}$ Also, systolic BP showed a decline from HUNT2 to HUNT3, with no difference between the PsA and the control group. This is in line with previous reports, but the reason for this decline in the population is uncertain. ${ }^{22}$ The beneficial effect of reduced salt and increased fruit and vegetable intake has been opposed by reduced physical activity and increased BMI. ${ }^{23}$

There are some limitations to our study. We did not adjust for potential important PsA clinical factors, such as use of DMARDs and steroids, disease duration of PsA or psoriasis and disease activity. We did not have information on fasting status for the serum lipids values; however, no significant variation between fasting and non-fasting levels of TC and LDL-c has been reported..$^{24}$ In this study, a relatively small part of patients with PsA were on biological medication $(9.9 \%)$ compared with present-day clinical experience. However, these data were registered up to 2008, at a point were the use of biological medications in Norway were more limited. Also, the patients with PsA were identified from a population survey, not a clinical hospital setting. However, almost 30\% were currently using methotrexate, and in addition almost $20 \%$ had used this medication previously. Further, 25\% had ever used leflunomide. We therefore believe that the patients with PsA from the HUNT study are comparable with the PsA population in Norway at the time of the study.

In summary, longitudinal 10-year data did not show an increase in CV risk factors in patients who developed PsA compared with the background population. However, at baseline, the patients who developed PsA had higher BMI, lower HDL-c and were more often smokers compared with the control group. This study indicates that unfavourable $\mathrm{CV}$ risk factors were present before the diagnosis of PsA was established, probably related to the fact that a majority of the patients with PsA already had psoriasis.

\footnotetext{
Author affiliations

${ }^{1}$ Department of Rheumatology, St. Olavs Hospital, Trondheim, Norway

${ }^{2}$ Department of Neuromedicine and Movement science, Norwegian university of Science and Technology, Trondheim, Norway

${ }^{3}$ Unit for Applied Clinical Research, Norwegian University of Science and Technology, Trondheim, Norway
}

${ }^{4}$ Department of Public Health and Nursing, Norwegian University of Science and Technology, Trondheim, Norway

${ }^{5}$ Department of Rheumatology, Allergy and Immunology, University of California San

Diego, San Diego, California, USA

${ }^{6}$ Preventive Cardio-Rheuma Clinic, Department of Rheumatology, Diakonhjemmet Hospital, Oslo, Norway

${ }^{7}$ Department of Rheumatology, Martina Hansens Hospital, Bærum, Norway

${ }^{8}$ Research Department, Hospital of Southern Norway Trust, Arendal, Norway

Acknowledgements The Nord-Trøndelag Health Study (The HUNT Study) is a collaboration between HUNT Research Centre (Faculty of Medicine, Norwegian University of Science and Technology NTNU), Nord-Trøndelag County Council, Central Norway Health Authority and the Norwegian Institute of Public Health. We thank clinicians and other employees at Nord-Trøndelag Hospital Trust for contributing to data collection in this research project.

Contributors AMG, MH: planning, interpretation of statistical analyses, writing. $\emptyset \mathrm{S}$ : planning, statistical analyses, writing. RST, AK, AGS, SR, GH: interpretation of statistical analyses, writing.

Funding The Liaison Committee between the Central Norway Regional Health Authority (RHA) and the Norwegian University of Science and Technology (NTNU). The funder had no involvement in study design, data collection, data analysis, manuscript preparation and/or publication decisions.

Competing interests None declared.

Ethics approval HUNT was approved by the Norwegian Data Protection Authority, and the study was approved by REK in South-Eastern Norway (number: 2010/2661).

Provenance and peer review Not commissioned; externally peer reviewed.

Data sharing statement Data from HUNT2 and HUNT3 can be made available after solicitation to the Nord Trøndelag Health Study (https://www.ntnu.edu/hunt).

Open Access This is an Open Access article distributed in accordance with the Creative Commons Attribution Non Commercial (CC BY-NC 4.0) license, which permits others to distribute, remix, adapt, build upon this work non-commercially, and license their derivative works on different terms, provided the original work is properly cited and the use is non-commercial. See: http://creativecommons.org/ licenses/by-nc/4.0/

(C) Article author(s) (or their employer(s) unless otherwise stated in the text of the article) 2018. All rights reserved. No commercial use is permitted unless otherwise expressly granted.

\section{REFERENCES}

1. Eder L, Wu Y, Chandran V, et al. Incidence and predictors for cardiovascular events in patients with psoriatic arthritis. Ann Rheum Dis 2016;75:1680-6.

2. Gladman DD, Ang M, Su L, et al. Cardiovascular morbidity in psoriatic arthritis. Ann Rheum Dis 2009;68:1131-5.

3. Gulati AM, Semb AG, Rollefstad S, et al. On the HUNT for cardiovascular risk factors and disease in patients with psoriatic arthritis: population-based data from the Nord-Trøndelag Health Study. Ann Rheum Dis 2016;75:819-24.

4. Jamnitski A, Symmons D, Peters MJ, et al. Cardiovascular comorbidities in patients with psoriatic arthritis: a systematic review. Ann Rheum Dis 2013;72:211-6.

5. Ogdie A, Yu Y, Haynes K, et al. Risk of major cardiovascular events in patients with psoriatic arthritis, psoriasis and rheumatoid arthritis: a population-based cohort study. Ann Rheum Dis 2015;74:326-32.

6. Soltani-Arabshahi R, Wong B, Feng BJ, et al. Obesity in early adulthood as a risk factor for psoriatic arthritis. Arch Dermatol 2010;146:721-6.

7. Gabriel SE. Heart disease and rheumatoid arthritis: understanding the risks. Ann Rheum Dis 2010;69(Suppl 1):i61-i64.

8. González-Gay MA, González-Juanatey C. Inflammation and lipid profile in rheumatoid arthritis: bridging an apparent paradox. Ann Rheum Dis 2014;73:1281-3.

9. Krokstad S, Langhammer A, Hveem K, et al. Cohort profile: the HUNT study, Norway. Int J Epidemiol 2013;42:968-77.

10. Hoff M, Gulati AM, Romundstad PR, et al. Prevalence and incidence rates of psoriatic arthritis in central Norway: data from the NordTrøndelag health study (HUNT). Ann Rheum Dis 2015;74:60-4.

11. Friedewald WT, Levy RI, Fredrickson DS. Estimation of the concentration of low-density lipoprotein cholesterol in plasma, without use of the preparative ultracentrifuge. Clin Chem 1972;18:499-502. 
12. Miller IM, Ellervik C, Yazdanyar S, et al. Meta-analysis of psoriasis, cardiovascular disease, and associated risk factors. J Am Acad Dermatol 2013;69:1014-24.

13. Challal S, Minichiello E, Boissier MC, et al. Cachexia and adiposity in rheumatoid arthritis. Relevance for disease management and clinical outcomes. Joint Bone Spine 2016;83:127-33.

14. Russolillo A, lervolino S, Peluso R, et al. Obesity and psoriatic arthritis: from pathogenesis to clinical outcome and management. Rheumatology 2013;52:62-7.

15. Love TJ, Zhu Y, Zhang Y, et al. Obesity and the risk of psoriatic arthritis: a population-based study. Ann Rheum Dis 2012;71:1273-7.

16. Gerdes S, Rostami-Yazdi M, Mrowietz U. Adipokines and psoriasis. Exp Dermatol 2011;20:81-7.

17. Eder L, Polachek A, Rosen CF, et al. The development of psoriatic arthritis in patients with psoriasis is preceded by a period of nonspecific musculoskeletal symptoms: a prospective cohort study. Arthritis Rheumatol 2017;69:622-9.

18. Kristensen LE, Jørgensen TS, Christensen R, et al. Societal costs and patients' experience of health inequities before and after diagnosis of psoriatic arthritis: a Danish cohort study. Ann Rheum Dis 2017;76:1495-501.
19. Ogdie A. The preclinical phase of PsA: a challenge for the epidemiologist. Ann Rheum Dis 2017;76:1481-3.

20. Carroll MD, Kit BK, Lacher DA, et al. Trends in lipids and lipoproteins in us adults, 1988-2010. JAMA 2012;308:1545-54

21. Hopstock LA, Bønaa KH, Eggen AE, et al. Longitudinal and secular trends in total cholesterol levels and impact of lipid-lowering drug use among Norwegian women and men born in 1905-1977 in the population-based Tromsø Study 1979-2016. BMJ Open 2017;7:e015001.

22. Hopstock LA, Bønaa $\mathrm{KH}$, Eggen $\mathrm{AE}$, et al. Longitudinal and secular trends in blood pressure among women and men in birth cohorts born between 1905 and 1977: the troms $ø$ study 1979 to 2008 . Hypertension 2015;66:496-501.

23. Danaei G, Finucane MM, Lin JK, et al. National, regional, and global trends in systolic blood pressure since 1980: systematic analysis of health examination surveys and epidemiological studies with 786 country-years and 5.4 million participants. Lancet 2011;377:568-77.

24. Sidhu D, Naugler C. Fasting time and lipid levels in a communitybased population: a cross-sectional study. Arch Intern Med 2012;172:1707-10. 